\title{
Diversity patterns exhibited by the Plecoptera of a Colorado mountain stream
}

\author{
J.V. Ward
}

Plecoptera collected from 11 locations along the longitudinal profile (first to fifth orders) of a Rocky Mountain stream (St. Vrain Creek) revealed distinctive spatial patterns of species diversity. Overall diversity was low near the stream source (epirhithron), attained maximum values in middle reaches, then declined dramatically concomitant with the transition from rhithron to potamon conditions. Shannon-Weaver index values (d) were $<1.0$ at high elevations and at the potamon station, whereas d exceeded 3.0 in middle reaches. Species richness based on summer data alone is depressed by nearly $50 \%$ at some locations, but the summer spatial pattern of $d$ values is in general concordance with that derived from the entire data set. Species diversity patterns of consecutive summers were relatively stable considering the substantial differences in discharge. To accurately determine Plecoptera diversity patterns, it was necessary to combine data from both fine $(240 \mu \mathrm{m})$ and coarse mesh $(720 \mu \mathrm{m}$ samples). Alt hough a myriad of interrelated factors determine the diversity of lotic insects at a given site, summer maximum temperature and annual temperature range appear to be major variables controlling the spatial diversity pattern of Plecoptera.

Distribution spatiale de la diversité spécifique des Plécoptères dans un cours d'eau de montagne du Colorado.

Des récoltes de Plécoptères dans onze stations situées le long d'un cours d'eau des Montagnes Rocheuses (du premier au cinquième ordre) ont montré une nette distribution dans l'espace de la diversité spécifique. Faible près de la source (épirhithron), la diversité globale at teint une valeur maximale dans le cours moyen puis baisse fortement lors du passage du rhithron au potamon. L'indice de Shannon-Weaver $(\bar{d})$ présente une valeur inférieure à un à haute altitude et dans la station du potamon alors qu'il dépasse trois dans le cuurs moyen. La richesse spécifique basée sur les seules données estivales est abaissée de près de $50 \%$ dans certaines stations mais la distribution dans l'espace des valeurs prises par d est en accord avec celle qui est basée sur l'ensemble des données. Cette distribution est restée stable pendant plusieurs étés successifs, malgré de fortes différences dans les débits. Pour établir de façon précise la distribution de la diversité des Plécoptères, il fallut combiner les données fournies par les récoltes effectuées avec un filet à mailles fines (240 $\mu \mathrm{m}$ ) et un filet à larges mailles $(720 \mu \mathrm{m})$. Bien qu'une multitude de facteurs interdépendants déterminent la diversité des insectes lotiques à chaque endroit, la température estivale maximale et l'amplitude annuelle des températures semblent être les principaux facteurs qui contrôlent la distribution dans l'espace de la diversité des Plécoptères.

\section{Introduction}

Since its embrace by the mainstream of modern community ecology (MacArthur 1957, Margalef 1957, Hutchinson 1959), the concept of species diversity has generated considerable interest and controversy and remains a central issue of ecological theory (Brown 1981). In aquatic habitats diversity indices have been commonly employed in studies of water quality (e.g., Wilhm \& Dorris 1968. Ghetti \& Bonazzi 1977, Bournaud \& Keck 1980) but only rarely have been applied to the macroinvertebrate communities of unpolluted waters (Ulfstrand 1975 , Stanford \& Ward 1983).

1. Department of Zoology and Entomology, Colorado State University, Fort Collins, Colorado B0523, U.S.A.
The primary purpose of this paper is to examine the spatial pattern of Plecoptera diversity in a Colorado stream system that traverses an extensive elevation gradient as it undergoes the transition from epirhithron to epipotamon conditions (sensu Illies \& Botosaneanu 1963). Secondary purposes include assessing the influence of mesh size, discharge, and year-round versus summer sampling on Plecoptera diversity patterns. See Ward (1982) for a list of species and their altitudinal limits (based on coarse mesh samples) in the study stream.

\section{1. - Study area and methods}

The diversity of a biotic community has two components. The species richness component in its sim- 
plest form is merely the number of species present. The evenness component relates to the distribution of individuals among the various species. The Shannon-Weaver function (Shannon \& Weaver 1949), which combines richness and evenness in a single measure, is used in the present study. It has been widely employed in studies of aquatic invertebrates and is relatively insensitive to sample size.

Sampling was conducted at 11 stations along the longitudinal profile of St. Vrain Creek (Fig. 1), a Cordilleran stream originating from snowmelt in the alpine tundra ( $3414 \mathrm{~m}$ a.s.l.) of northern Colorado. Lower and middle elevation stations were sampled monthly (June 1975 - September 1976); the uppermost stations were inaccessible during the extended period of snowcover, which limited monthly sampling to the two consecutive summers.

Six samples (each $0.09 \mathrm{~m}^{2}$ ) were collected from each site on each date with Surber samplers equipped with fine $(240 \mu \mathrm{m})$ and coarse mesh $(720 \mu \mathrm{m})$ nets. Within-site and between-site differences in substrate and current were minimized by confining sampling to rubble riffles, the predominant habitat type. Dissolved oxygen was near saturation at all locations. Whereas thermal conditions exemplified the transition from epirhithron (Site 1) to epipotamon (Site 11), other factors (oxygen, substrate, current) maintained rhithron characteristics along the entire stream profile.

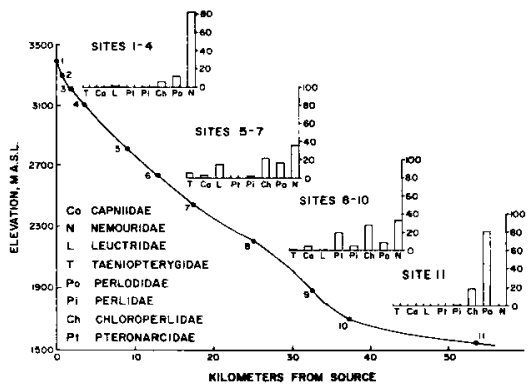

Fig. 1. Longitudinal profile of St. Vrain Creek, Colorado, with site locations indicated by Arabic numerals. Histograms show the relative contribution ( $X \%$ composition by numbers, year 1 , coarse mesh) of families to total Plecoptera. Values $<1 \%$ are not indicated.

\section{2. - Results and discussion}

All of the North American families of Plecoptera except Peltoperlidae are represented in the study stream (Fig. 1). St. Vrain Creek has a slightly greater familial and generic diversity than the Plecoptera fauna of the Pyrénées, but only 33 species were collected compared to $\mathbf{7 8}$ for the Pyrénées (Berthélemy 1966). Because the Rocky Mountains are aligned roughly N-S, Pleistocene glaciation did not result in the long-term isolation of Plecoptera as occurred in Europe where populations differentiated within numerous mountain refugia to form many endemic species (Illies 1953).

Total Plecoptera diversity of the study stream was low in the headwaters, at tained maximum values in middle reaches, then declined dramatically concomitant with the transition from rhithron to potamon conditions (Fig. 2). Because the open season is so short at high elevations, it is unlikely that any common species were missed despite the more restricted sampling periods at headwater stations. Midwinter sampling through the ice during a winter of extremely low snowfall (1981), which allowed access to upper stations, failed to yield additional species. Shannon-Weaver values ( $\bar{d})$ and species richness exhibited generally similar spatial patterns. The decline in $\bar{d}$ from Station 1 to 2 , despite constant or increasing species richness, results from the extreme numerical dominance by Zapada oregonensis at Station 2, especially during year 2 . The dip in $\mathrm{d}$ values between Stations 6 and 10 is primarily attributable to the development of large populations of Prostoia besametsa and Eucapnopsis brevicauda at the intervening stations.

Species diversity values are depressed if only summer data are utilized (Fig. 2). This is especially apparent for species richness. The number of species encountered during summer represent only slightly more than half of the total Plecoptera fauna at some locations in the middle reaches. The lower number of species in summer is partly a function of missing rare species when examining a smaller number of samples and partly a direct result of the restricted sampling period as it relates to life cycle patterns. Many Plecoptera are univoltine with fast seasonal cycles (sensu Hynes 1970) and remain in egg diapause throughout the summer. Obviously the nymphs of such species would not normally appear 

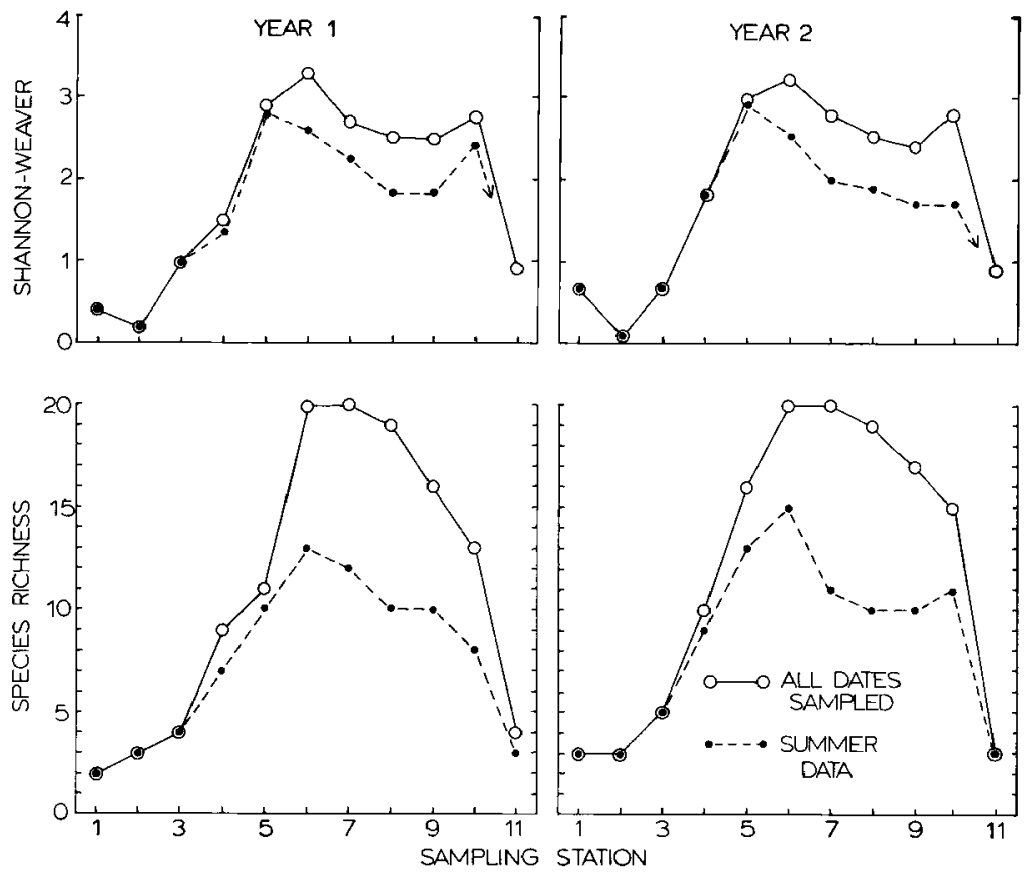

Fig. 2. Spatial diversity patterns of Plecoptera based on Shannon-Weaver index values $(\overline{\mathbf{d}})$ and species richness for two overlapping one-year periods. Year 1 (June 1975-May 1976) included a spring runoft period with high discharge ; year 2(Oct. 1975-Sept. 1976) exhibited a normal spring runoff. Sampling was confined to the summer at the upper three stations. Numbers collected during the summers at Station 11 were insufficient for valid $d$ calculations. Based on a composite of fine and coarse mesh data.

in summer collections. For example, nymphs of Prostoia besametsa first appear in samples in December or Junuary and most have emerged by June; nymphs of Taenionema nigripenne appear in October or November and most have emerged by May. It is therefore possible to completely miss common species by restricting sampling to the summer period.

The reductions in $\overline{\mathbf{d}}$ values when based solely on summer data are relatively small (Fig. 2). The spatial patterns of Shannon-Weaver diversity from sum- mer data are in general concordance with those derived from the entire data set, although maximum $\bar{d}$ values occur at Station 5 rather than Station 6 during both years.

Because of an especially high snowpack the preceding winter, year 1 had a higher discharge and an extended period of runoff compared to year $2(\bar{X}$ summer discharge at Station 6 of 2.2 and $1.0 \mathrm{~m}^{3}$ $\mathrm{sec}^{-1}$, respectively). Although Plecoptera density estimates were responsive to changes in the flow regime of successive years, species diversity pat- 
terns remained relatively stable (compare solid circles in Fig. 2), considering the dramatic differences in summer discharge (including effects on sampling efficiency). Diversity values at many stations were somewhat higher the second summer, but at others they were slightly lower or at the same level.

The importance of mesh size in sampling stream macroinvertebrates has been considered largely as it affects density and biomass estimates. Because of reports that fine mesh nets, while more efficient in retaining small organisms, may less efficiently sample larger and more active animals such as certain Plecoptera (Mackereth 1957, Zelt \& Clifford 1972), both fine $(240 \mu \mathrm{m})$ and coarse mesh $(720 \mu \mathrm{m})$ were utilized in the present study. At some locations the mesh size of the sampler markedly influenced Plecoptera diversity values (Fig. 3). In six instances, data from either fine or coarse mesh yielded diversity estimates at least $50 \%$ greater than values derived from the other mesh size at a given location ( $\bar{d}$ at Stations 1, 2, 7; species richness at Stations 1 2,11 ). In four of these six cases fine samples yielded the higher diversity. Similar results were obtained during year 1 (nos shown), except that in all cases (where difference exceeded $50 \%$, an arbitrary level) coarse samples yielded the higher values.

Results from diversity calculations based on the combined data from coarse and fine samples add yet another dimension. In most cases $\bar{d}$ values from the combined data are intermediate, but at two stations values are slightly higher than those derived from either mesh size (indicated by open triangles in Fig. 3). At seven locations composite samples yield more species of Plecoptera than either mesh size considered separately. The increased species richness results partly from doubling sample size by combining coarse and fine data and partly from speciesspecific differences in retention as a function of mesh size (see Zelt \& Clifford 1972). Common species that consistently occurred in greater numbers in fine samples include the nemourid Prostoia besametsa and the capniid Eucapnopsis brevicauda. Other species, including Pteronarcella badia, were better represented in coarse samples, and the larger pteronarcid Pteronarcys californica was collected only with coarse mesh. In the present study, plecopterans missed with one or the other mesh were generally rare species or species that were rare locally (i.e., marginal populations).
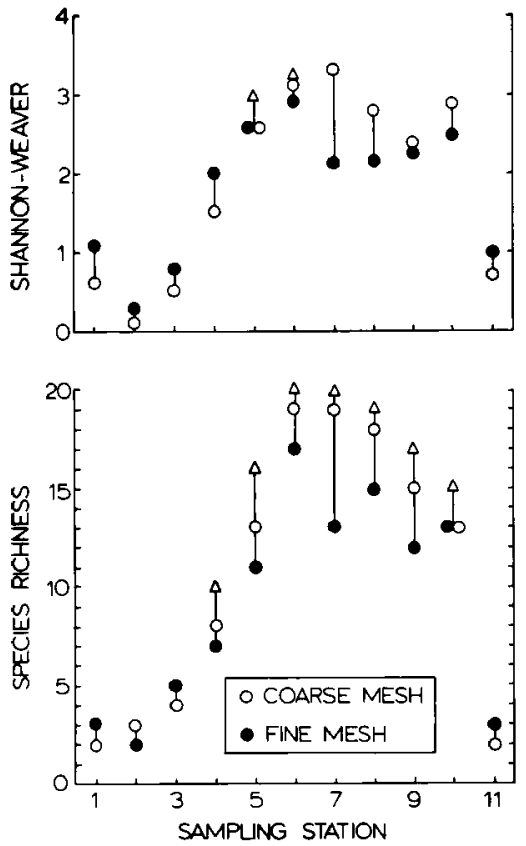

Fig. 3. Shannon-Weaver diversity and species richness data based on coarse $(720 \mu \mathrm{m})$ and fine mesh $(240 \mu \mathrm{m})$ collections of Plecoptera (combined from all dates during year 2). Open triangles are used to designate composite diversity only where the combined date from coarse and fine mesh samples result in greater values than either mesh size.

Ulfstrand (1975) reported that the species richness component governed the total Plecoptera diversity in Lapland streams. Data from the present study suggest that Shannon-Weaver diversity and species richness should both be considered when attempting to characterize Plecoptera diversity patterns in lotic ecosystems. Bournaud \& Keck (1980) also concluded that while species richness alone is a sensitive indicator of environmental conditions, the use of additional diversity indices increases the accu. racy of the interpretation. 


\section{3. - Conclusions}

An eminent American zoologist recently stated that "One of the greatest remaining challenges in biology is to explain the diversity of living things " (Brown 1981, p. 877). The present paper has examined Plecoptera diversity along the longitudinal profile of a mountain stream, but does not presume to provide a definitive explanation for the observed spatial pattern. Species diversity patterns are determined by a myriad of interrelated, and often poorly understood, factors. Several investigators have, however, proposed temperature as a major factor controlling altitudinal distribution patterns of aqua. tic insects (see Ward \& Stanford 1982), and this appears especially applicable to Plecoptera (Brinck 1949). As previously stated, the sampling program for St. Vrain Creek allows certain other variables to be eliminated as major determinants of Plecoptera diversity.

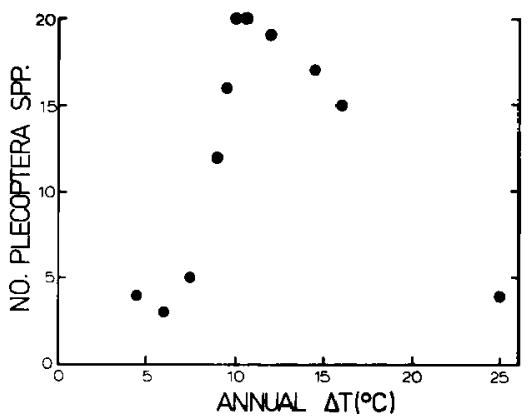

Fig. 4. Plecoptera species richness (combined data from coarse and fine mesh on all dates) as a function of annual temperature range.

The relationship between diversity and the annual temperature range for the study stream (Fig. 4) is similar to that exhibited by the Plecoptera fauna of the Flathead River system in Montana (Stanford \& Ward 1983). At high elevation headwater stations in St. Vrain Creek diversity is undoubtedly limited by the general severity of conditions, including the extended period of ice and snow cover $(7+$ months per year), low summer temperatures $\left(\leqslant 6^{\circ} \mathrm{C}\right)$, and a limited number of annual degree days $(<500)$. The few plecopterans able to tolerate conditions at upper stations were primarily eurythermal species (Zapada oregonensis, Megarcys signata) whose distributions encompassed a wide range of elevation (Ward 1982).

Although a diverse and abundant insect fauna occurs at Station 11 (epipotamon), most Plecoptera are unable to tolerate summer tempera tures which frequently exceed $20^{\circ} \mathrm{C}$ and attain maxima of $25^{\circ} \mathrm{C}$. In the middle reaches where Plecoptera species richness is maximized, there is sufficient thermal diversity for considerable niche diversification, yet temperatures do not exceed $16^{\circ} \mathrm{C}$.

Plecopterans are the most cool adapted and rheophilic of the aquatic insect orders. The stonefly fauna of mountain st reams has evolved in response to predictable thermal heterogeneity. A broad annual temperature range, provided maximum values do not exceed certain limits, has facilitated temporal niche segregation mechanisms and enhanced species diversity. It appears that temperature has played a major role in structuring Plecoptera diversity patterns along the longitudinal profile of stream systems.

\section{Acknowledgements}

The author is grateful 10 Dr. R.W. Pennak for valuable comments regarding the manuscript and co Mr. J.H. Harey for laboratory assistance, Drs. R.W. Baumann, S.G. Jewett, K.W. Stewart, S.W. Szczytko, J.A. Stanford, and R.F. Surdick provided valuable taxonomic assistance.

\section{Literature cited}

Berthélemy (C.). 1966 - Recherches écologiques et biogéographiques sur les Plécoptères et Coléoptères d'eau courante (Hydraena el Elminthidae) des Pyrénées. Annls. Limnol., 2: 227.458 .

Bournaud (M.) \& Keck (G.) 1980 - Diversité spécifique et st ructure des peuplements de macro-invertébres benthiques au long d'un cours deau: Le Furans (Ain). Acta Decologic/Oecol. Gener., $1=131+150$.

Brinck (P.). 1949. - Studies on Swedish stoneflies (Plecoptera). Opusc. Ent. Suppl. 11: 1-250.

Brown (J.H.). 1981. - Two decades of homage to Santa Rosalia : toward a general theory of diversity. Am. Zool., $21: 877-888$.

Ghetti (P.F.) \& Bonazzi (G.). 1977. - A comparison between various criteria for the interpretation of biological data in the analysis of the quality of running waters. Water Research, $11: 819-831$. 
Hutchinson (G.E.). 1959. - Homage to Santa Rosalia, or why are there so many kinds of animals? Am. Nat., 93 : 145-159.

Hynes (H.B.N.). 1970. - The Ecology of Running Waters. Univ. Toron to Press, Toronto, $555 \mathrm{p}$.

Illies (J.). 1953. - Beitrag zur Verbreitungsgeschichte der europäischen Plecopteren. Arch. Hydrobiol, 48 : 35-74.

Illies (J.) \& Botosaneanu (L.). 1963. - Problemes et methodes de la classification el de la zonation écologique des eaux courantes, considérées surtout du point de vue faunistique. Mitt. Intemat. Verein. Limnol., $12: 1-57$.

Mac Arthur (R.H.). 1957, - On the relative abundance of bird species. Proc. Nat. Acad. Sci. USA, $43: 293-295$.

Mackereth (J.C.). 1957. - Notes on the Plecoptera from a stony stream. J. Anim. Ecol, $26: 343-351$.

Margalef (R.). 1957. - La teoria de la informacion en ecologia. Mem. Real Acad. Cienc. Artes Barcelona, 32: 373-449.

Shannon (C.E.) \& Weaver (W.). 1949. - The mathematical theory of communication. Univ. Illinois Press, Urbana. $117 \mathrm{p}$.

Stanford (J.A.) \& Ward (J.V.). 1983. - Insect species diversity as a function of environmental variability and disturbance in stream systems, p. 265-278. In : J.R. Bames \& G.W. Minshall (eds.). Stream Ecology - Application and testing of General Ecological Theory. Plenum Press, New York.

Ulfstrand (S.) 1975. - Diversity and some other parameters of Ephemeroptera and Plecoptera communities in subarctic nunring waters. Arch. Hydrobiol, $76: 499.520$.

Ward (J.V.), 1982. - Altitudinal zonation of Plecoptera in a Rocky Mountain stream. Aquatic Insects, $4: 105-110$.

Ward (J.V.) \& Stanford (J.A.). 1982. - Thermal responses in the evolutionary ecology of aquatic insects. Ann. Rev. Entomol., $27: 97-117$.

Wilhm (J.L.I \& Dorris (T.C.). 1968. - Biological parameters for water quality. BioScience, $18: 477.481$.

Zelt (K.A.) \& Clifford (H.F.). 1972. - Assessment of two mesh sizes for interpreting life cycles. standing crop, and percentage composition of stream insects. Freshwater Biol., $2: 259.269$. 